\title{
PHILOSOPHY AND THEOLOGY IN AN ORAL CULTURE: RENAISSANCE HUMANISTS AND RENAISSANCE SCHOLASTICS
}

\author{
Amos Edelheit
}

Vrin | «Revue des sciences philosophiques et théologiques »

2014/3 Tome 98 | pages 479 à 496

ISSN 0035-2209

Article disponible en ligne à l'adresse :

https://www.cairn.info/revue-des-sciences-philosophiques-ettheologiques-2014-3-page-479.htm

Distribution électronique Cairn.info pour Vrin.

(C) Vrin. Tous droits réservés pour tous pays.

La reproduction ou représentation de cet article, notamment par photocopie, n'est autorisée que dans les limites des conditions générales d'utilisation du site ou, le cas échéant, des conditions générales de la licence souscrite par votre établissement. Toute autre reproduction ou représentation, en tout ou partie, sous quelque forme et de quelque manière que ce soit, est interdite sauf accord préalable et écrit de l'éditeur, en dehors des cas prévus par la législation en vigueur en France. Il est précisé que son stockage dans une base de données est également interdit. 


\title{
PHILOSOPHY AND THEOLOGY IN AN ORAL CULTURE : RENAISSANCE HUMANISTS AND RENAISSANCE SCHOLASTICS
}

\author{
by Amos EDELHEIT \\ National University of Ireland, Maynooth
}

Sermons were an essential part of a dynamic oral culture of the Renaissance, where we find a blend of traditional and new forms such as public speeches for different occasions, introductory lectures for university courses, public debates in the universities, in the houses of learning of the different religious orders and in private palaces and villas, and special sermons delivered in the many different religious confraternities. This is the proper historical context for understanding the role of sermons in the Renaissance; in many cases these sermons reflect important aspects of the new cultural atmosphere we call "the Renaissance", which does not always correspond to some popular and old historiographical images of a secular and anti-religious movement ${ }^{1}$.

We can still find in the Renaissance a tendency towards the convivio and the more open and less academic and formal debates. One example for this can be found in Nicolaus de Mirabilibus, a Dominican (who was regarded by Ficino as « a living statue of Thomas ») who participated in an important public debate which took place in Florence in 1489. On the last page of his written account of the debate, Nicolaus regards the event

1. On this see the classical study by John O'Malley, Praise and Blame in Renaissance Rome - Rhetoric, Doctrine, and Reform in Sacred Orators of the Papal Court 1450-1521, Durham, Duke University Press, 1979. 
which took place in Lorenzo de Medici's palace as a quaestio disputata ${ }^{2}$. This is the technical scholastic or academic term. But in his short opening section, while addressing Lorenzo, to whom he dedicated his account, he is using a more general term which is much closer to Lorenzo's Platonic circle : convivium ${ }^{3}$. There is nothing strange here : the participants who were invited by Lorenzo to his palace enjoyed his generous hospitality before going on with the debate. On the next page Nicolaus mentions Plato's ideal of combining political power and wisdom while praising Lorenzo for his initiative of both the convivium and the disputatio. The analogy between Plato's philosopher-king and Lorenzo is explicitly pointed out. What is also obvious is that Nicolaus is well aware of the humanist fashion in Florence, just as Poliziano, Ficino, and Pico for instance, were interested in this scholastic debate. Combining a convivium and a disputatio seemed perfectly reasonable for the participants and part of their intellectual environment. Let us say something more about this environment.

Some long-standing scholarly views concerning Renaissance humanism have been revised in recent years. Ronald Witt's volumes revising the starting-point of the humanist movement and fashion in Italy (around the middle of the thirteenth century instead of the midfourteenth century - that is, two generations before Petrarch, the socalled "father" of Renaissance humanism), and dealing with the most crucial discipline for this starting-point (grammar instead of rhetoric) is one obvious example for this ${ }^{4}$. Another is the view concerning the relations between Renaissance humanism and the humanists on the one hand and philosophy on the other. In this case as well, more adequate

2. Nicolaus De Mirabilibus, Disputatio nuper facta in domo Magnifici Laurentii Medices, Florence, Per Francischum dini iacobi, 1489, p. 13 : «Finis questionis disputate in domo Magnifici Laurentii Medices ultima die Iunii M.cccc.lxxxviiii. » On Nicolaus see my Scholastic Florence. Moral Psychology in the Quattrocento, Leiden, Brill, 2014, chapter 1.

3. Ibid., p. 1 : « Post convivium illud abs te Magnifice Laurenti magnifice ac splendide factum redeunti mihi domum et disputationis illius nostre decisiones ac determinationes mente et animo revolventi... »

4. Ronald G. WITT, "In the Footsteps of the Ancients". The Origins of Humanism from Lovato to Bruni, Leiden, Brill, 2000; The Two Latin Cultures and the Foundation of Renaissance Humanism in Medieval Italy, Cambridge, Cambridge University Press, 2012. But see the review article on the second volume in Alexander MURRAY, « Out of Limbo. Devotion, Erudition and an Anticlerical Strain in a Remarkable Study of the "AllConquering Classical Enthusiasm" that Nourished the Renaissance », in the Times Literary Supplement (January 11, 2013), p. 3-4, for some limitations in Witt's perspective concerning theological matters and the role of religion in the Italian Renaissance. 
scholarly accounts were needed in order to revise some so-called "standard" views".

And what about the humanists and theology? Many historians of Renaissance humanism still ignore one crucial phenomenon, the religious confraternities, where humanists were active and delivered sermons to their members, sermons which were steeped in humanist culture. Let us examine now a few sermons by humanists found in MS Riccardiana 2204. This manuscript was used e.g. by Cesare Vasoli for his 1973 edition of the first five sermons of Giovanni Nesi ${ }^{6}$, but it also contains other sermons which can be used to further our study of the connection between humanists and theology.

In a sermon entitled Exortatio ad osculum crucis, delivered by Francesco Berlinghieri to the confraternity of St Vincentio in 1476, we find the usual mixture of Neoplatonism, theology, and the Scriptures ${ }^{7}$.

5. Humanism, according to Paul Oskar Kristeller, was an important cultural movement, but it was focused on a very specific part of culture, basically the linguistic disciplines. He saw no relation between the humanists' interest in rhetoric (both in theory and in practice), their new attitude to Aristotle and Cicero, their critique of scholasticism, their political activity, and their philosophical view-point. See, e.g., P. O. KRISTELLER, « Humanism and Scholasticism in the Italian Renaissance », in Studies in Renaissance Thought and Letters, Rome, Edizioni di storia e de letteratura, 1956, p. 553-583; especially p. 560-574. For a more adequate perspective of the relations between the humanists and philosophy see Jill KRAYE, «Philologists and Philosophers », in J. KRAYE (ed.), The Cambridge Companion to Renaissance Humanism, Cambridge, Cambridge University Press, 1996, p. 142-160.

6. Cesare VAsoli, « Giovanni Nesi tra Donato Acciaiuoli e Girolamo Savonarola Testi editi e inediti », Memorie Dominicane 4 (1973), p. 103-179. The sermons are on p. 123-160. Other manuscripts of humanist's sermons mentioned by Vasoli are Florence, Biblioteca Nazionale Centrale, Magl. XXXV. 211; Florence, Accademia Toscana di Scienze e Lettere «La Colombaria», 247. On the activity of the humanists in the religious confraternities in the Florentine context see especially KRISTELLER'S «Lay Religious Tradition and Florentine Platonism », in Studies in Renaissance Thought and Letters, Roma, Edizioni di storia e de letteratura, 1969, p. 99-122 ; and Ronald F. E. WEISSMAN's «Sacred Eloquence - Humanist Preaching and Lay Piety in Renaissance Florence », in Timothy VERDON and John HENDERSON (eds.), Christianity and the Renaissance. Images and Religious Imagination in the Quattrocento, New York, Syracuse University Press, 1990, p. 250-271.

7. Florence, Biblioteca Riccardiana, ms. 2204, f. 165r : «Questa gloria, questo lume andando investigando alcuni principali phylosophi sommo bene epsi chiamarono. Platone di tutti sapientissimo questo divino furore apellava. Socrate di lui maestro solo la mente delle operatore del bene al celo doven tuornare confessava [this is a reference to themes which recur in Plato's Phaedrus]. Paulo et Dyonisio Ariopagita fra nostri cristiani insigni et celeberrimi theologi Noi glinvisibili et segreti misterii di dio in questa vita potere argumentare per li effecti et cose maravigliose da noi viste affermarono. Questa gloria vide et cognobbe inhuman corpo David propheta ; onde namorato del sommo giesu ogni giorno allui parlando diceva. Zelus domus tuae commedit me [ $7 n$ 2, 17, from Ps 69, 10] et altrove. Ad te levavi oculos meos : qui habitas in celis $[P s$ 123, 1]. » On the theme of 
In another sermon, on Christ's body, delivered by Giovanni Cocchi to the confraternity della nativita di cristo in March 23, 1474, we find an account of the Eucharist and of the limitations of language :

Taking into account that, just as St Thomas says in the sermon mentioned above : there is no one who can, with a human intellect, understand, nor with a mortal language explain, the sweetness of such a sacrament. ${ }^{8}$

The phrase « mortal language » borrowed from Thomas becomes relevant in the context of humanist theology, in which there is a sharp distinction between language, as a human product, and religious truth, which means that the study of language and philology cannot deal with religious truth. This can be seen from the sermon by Christoforo Landino on Christ's body delivered to the confraternity of the Magi, where we find the same phrase :

Here is why I am so confident in my most weak power, which imitates with mortal language [in an effort] to express the divinity ? ${ }^{9}$

The Divine cannot be expressed by means of a mortal language on account of its mortal nature ; language therefore becomes part of history and the human sciences. The separation between humanity and divinity is an instrument employed by humanists to establish new methods and a new rhetoric in theological discussions, as well as a new and more practical religious life. This obvious distinction - so common in the theological investigations of the Fathers and Doctors of the Church takes on a new meaning in the context of the development of humanist methods and the humanist critique of scholastic theology. Landino, like other humanists, criticizes the methods of scholastic theology: syllogisms, logical arguments, and demonstrations, which, he says, belong to the via naturale; in confronting the mysteries of faith,

divine frenzy in Ficino see Sebastiano GeNTILE, «In margine all'epistola "De divino furore" di Marsilio Ficino », Rinascimento 21 (1981), p. 33-77. On the theme of holy madness in the poetry of the Renaissance see Lauro MARTINES, Strong Words. Writing and Social Strain in the Italian Renaissance, Baltimore, John Hopkins University Press, 2001, p. 52-58.

8. Ibid., f. 169r : « Considerato che come dice san Thommaso nel prealegato sermone : none alcuno che possa con intellecto humano intendere, ne con lingua mortale exporre la suavita di tal sacramento... » In the Summa theologiae III $^{\mathrm{a}}$, q. 74, a. 3, we have « Hoc autem sacramentum pertinet ad suave jugum Christi... » I could not find the reference to the mortal language in Thomas. But see Lactantius, Divinae institutiones I, 3, 15 : « qua in re quoniam et sensu deficimur et verbis, quia neque tantum intellegentiae lucem pectus humanum neque explanationem tantarum rerum capit lingua mortalis, id ipsum intellegere nos oportet ac dicere. »

9. Ibid., f. $176 \mathrm{v}:$ « o perche tanto nelle debilissime mie forza presummo che mimetta con lingua mortale a exprimere la divinita. » 
however, we should instead contemplate the mysterious Sacrament by means of the sopranaturale via ${ }^{10}$. He, too, thus emphasizes the gap between the finite and infinite, and the need for the practice of devotion in order for finite man to feel closer to the divine. It is important to note that Landino does not mention any Doctor of the Church.

Donato Acciaiuoli, in a sermon on Christ's body, delivered to the confraternity of the Magi in 1468, expresses the same idea of a gap between human intelligence and divine matters :

In considering the sacred excellence and supreme dignity, there is no intellect which does not become diminished, no sense which does not remain confused, no language which does not become mute. ${ }^{11}$

Acciaiuoli also shares the tendency common in the sermons of many humanists of translating, and thus disseminating, Latin citations for his listeners. He mentions Jerome and Augustine, but no Doctors of the Church. Jerome and Augustine are quoted by other humanists, probably because of their special status as the translator of Scripture and the most influential and most widely read Church Father. But did all the

10. Ibid., f. $172 \mathrm{v}:$ «... ci comanda et costrigne non solo ad humilitare una afare prigionere, la quale nostre menti informa che posto da parte ogni inquisitione, la quale per sylogystici argumenti cerca la dimostratione et scientia della cosa alla sola fede con sincera et ardente carita ci sotto mettiamo che havendo a contemplare il sacratysimo misterio del verace per corpo di christo, el quale non per naturale ma per sopranaturale via nellazimo pane discendere ma la sincera indubitata et constante fede ci sara ghuida. »

11. Ibid., f. 180r : « ... perche considerando la sacra excellentia et supprema dignita none mente alcuna che non vengha manco, none senso che non rimanga confuso, none lingua che non diventa muta. » This sermon is discussed in some detail by Charles TRINKAUS in Our Image and Likeness - Humanity and Divinity in Italian Humanist Thought, vol. 2, Chicago, London, University of Chicago Press, 1970, p. 644-647. Trinkaus claims that Acciaiuoli's sermon « is without doubt an example of an Italian devotio moderna, fully in the spirit of the humanistic studies towards which Acciaiuoli was equally devoted. Moreover, the doctrinal content is essentially evangelical and pious, rather than doctrinal, metaphysical, or theological. And yet he was, as is known, an Aristotelian and spokesman, perhaps, of Argyropoulos' interpretation of the Stagirite, shown recently by Garin to have shared certain attitudes also expressed through Ficino's Platonism » (p. 647). Already in these cited lines there is an unsolved conflict between the devotional, evangelical, and the non doctrinal or metaphysical or theological style on the one hand, and the humanistic philosophical background on the other. Such a dichotomy simply does not work (it originated in Kristeller's problematic distinction between humanism and philosophy). Thus, Trinkaus' phrase theologia rhetorica misses both the humanists' critique of scholastic theology, and the alternative offered by humanist theology, which is not only rhetorical but also doctrinal. The doctrinal aspect of this new theology drew on the humanists' new perspective regarding the studia divinitatis (both patristic and scholastic theology and the Scriptures), and the studia humanitatis (both the new classical textual corpora, some of which were completely unknown in the Middle Ages, and the new methods of philology and history). 
humanists and Renaissance philosophers share this view of criticizing scholastic theology and restricting philosophical terminology and practices in theological discussions?

One of the most famous documents in our Renaissance legacy is a speech which was never delivered: Giovanni Pico della Mirandola's opening speech for his intended public debate on his 900 theses, written in 1486 and later known as Pico's Oration on the Dignity of $\mathrm{Man}^{12}$. As we shall shortly see Pico held other views regarding scholastic philosophy and theology and regarding the proper relation between philosophy and theology.

Pico's statement that we emulate in our present life the cherubic life (nos cherubicam in terris vitam aemulantes...) is a reference to the opening section of the Oration (where Pico discusses the place of man in the cosmos) but it also reflects the crucial role of philosophy according to Pico. He uses the phrase «we should purify the soul» (animam purgemus) as an image, expressing the improvement of our moral behaviour and intellectual abilities. Immediately next in the order of progression - and it should be clear by now that Pico is intentionally employing an admixture of theological images and standard philosophical distinctions, using the discourse of spiritual progression as an analogy for philosophical progression - comes the light of natural philosophy which we should imbue (perfundamus), and at last (postremo), the understanding of that part of philosophy which deals with divine matters which we should perfect (perficiamus) ${ }^{13}$. Interestingly, the second stage, being imbued with the light of natural philosophy, is not entirely the same as being illuminated, and it shows that Pico is aware of the potential tension between theological and philosophical speculations.

Further evidence for Pico's awareness of the theology-philosophy tensions, and for his intention to move away from a too strict distinction between "theology" and "philosophy", is provided in his statement that the philosopher Empedocles should interpret for us the words of Job the theologian. This is somehow justified by a hermeneutical practice according to which the order in the middle (medius ordo) should interpret for those in the lower place the teachings (monita) of the supreme order. Pico is turning these institutional tensions between the two disciplines into an inner tension which originates from human

12. Giovanni Pico della Mirandola, Oratio de hominis dignitate, now reedited by Francesco BAUSI under the title Discorso sulla dignità dell'uomo, Parma, Guanda, 2003 ; repr. 2007.

13. G. Pico della Mirandola, Discorso sulla dignità dell'uomo, p. 28-30 : «Tum bene compositam ac expiatam animam naturalis philosophiae lumine perfundamus, ut postremo divinarum rerum eam cognitione perficiamus. » 
psychology, which, according to Empedocles, contains a double nature (duplex natura) : one which drags us to celestial matters, and another which pushes us downwards towards lower things. The result of having these two contrasted natures is either having a war and a conflict between them or having peace and friendship ${ }^{14}$. It is quite easy to identify the resemblance between Empedocles' conception of human nature as it is depicted here by Pico, and Pico's own conception stated in the first section of the Oration. Man can move up or down either according to his two natures (Empedocles), or thanks to his unique ability and transforming nature (transformans natura) given to him by God to choose his own destiny (Pico). This double nature is the cause of discord and restlessness in our soul. In order to reach peace and harmony we need, first of all, moral philosophy, and then, once again, dialectic, natural philosophy and finally theology.

It is important to notice again the crucial role of theology in this context : theology, just like philosophy, becomes an object of investigation for the historian and interpreter of philosophy as long as it is part of human progression and development. It is both part of a historical and a psychological reality, and thus an essential part of that reality itself. In other words : if theological discourse (verba) has any meaning it must be connected to the reality (res), and so, it should be part of any significant account of that reality. The fact that scholastic philosophy has so many complex relations with theological issues is yet another good reason not to disregard this philosophical tradition.

Friendship (amicitia) is regarded as the end and purpose of philosophy according to the Pythagoreans, and in the same way peace (pax), which was created by God, is announced by the angels to human beings with good will, so that when they ascend to heaven they would become angels ${ }^{15}$. This peace is in fact what we would call "a state of mind" thanks to which our soul becomes God's home (ipsa Dei domus fiat), and after which purification is possible through moral philosophy, dialectic and again theology. Beyond the poetic images and language which are expected in a speech we find here again Pico's consistent effort to combine philosophical and theological concepts. What is the purpose of such an effort? It might just be to show that theology has also a history and this is an important step beyond the Eusebian project

14. Ibid., p. 36-38: «Hic duplicem naturam in nostris animis sitam, quarum altera sursum tollimur ad caelestia, altera deorsum trudimur ad inferna, per litem et amicitiam, sive bellum et pacem, ut sua testantur carmina, nobis significat. »

15. Ibid., p. 42 : «Haec est illa amicitia quam totius philosophiae finem esse Pythagorici dicunt; haec illa pax quam facit Deus in excelsis suis, quam angeli in terram descendentes annuntiarunt hominibus bonae voluntatis $[L c 2,13]$, ut per eam ipsi homines ascendentes in caelum angeli fierent. 》 
of the Praeparatio Evangelica (natural revelations followed by divine revelation) which is an ahistorical project. Since theology, as we have seen, plays such a significant role in human experience, psychology and development, it becomes a legitimate subject for the interpreter and for interpretation. It is thus not only the Mosaic or the Christian mysteries but also the theology of these ancients (priscorum quoque theologia) which shows us the benefits and dignity of liberal arts. Since - Pico asks - what other purpose these progressions attended by the initiaters in the secret rites of the Greeks have but purifications, and this process begins with moral philosophy and dialectic which are regarded as almost purifying arts (quasi februales artes) in the undertaking of the mysteries. What else do we have here, claims Pico, but the interpretation of the more secret nature through philosophy? And this is followed by the Divine Vision - غं $\pi$ $\pi \tau \varepsilon i \alpha$ - the investigation of divine matters through the light of theology ${ }^{16}$.

Pico continues to "cross the lines" in his defense of public debates on philosophical and theological matters : the scholastic practice of a public debate is regarded by the young philosopher as an essential part of philosophy and it is related by him to Plato, Aristotle and to the very best philosophers in any era. The very best Doctors (doctores excellentissimi) performed those debates just as the best ancient philosophers ${ }^{17}$. By doing this Pico is creating a philosophical continuity between classical and scholastic philosophies and he rejects any sharp distinction between these two traditions, and thus any exclusive approach which prioritizes the philosophical culture of classical antiquity over medieval philosophical culture. An historical awareness of the differences between these two periods does not mean dismissing an

16. Ibid., p. 48 : «Verum enimvero, nec Mosayca tantum aut Christiana mysteria, sed priscorum quoque theologia harum, de quibus disputaturus accessi, liberalium artium et emolumenta nobis et dignitatem ostendit. Quid enim aliud sibi volunt in Graecorum archanis observati initiatorum gradus, quibus primo, hercle, per illas quas diximus quasi februales artes, moralem et dialecticam, purificatis, contingebat mysteriorum susceptio? Quae quid aliud esse potest quam secretioris per philosophiam naturae interpretatio ? Tum demum ita dispositis illa adveniebat غ́ $\pi 0 \pi \tau \varepsilon \dot{\alpha} \alpha$, idest rerum divinarum per theologiae lumen inspectio. »

17. Ibid., p. 76: «Primum quidem ad eos, qui hunc publice disputandi morem calumniantur, multa non sum dicturus, quando haec culpa, si culpa censetur, non solum vobis omnibus, doctores excellentissimi, qui sepius hoc munere non sine summa et laude et gloria functi estis, sed Platoni, sed Aristoteli, sed probatissimis omnium etatum philosophis mecum est communis. Quibus erat certissimum nihil ad consequendam quam querebant veritatis cognitionem sibi esse potius, quam ut essent in disputandi exercitatione frequentissimi. Sicut enim per gymnasticam corporis vires firmiores fiunt, ita dubio procul, in hac quasi literaria palestra animi vires et fortiores longe et vegetiores evadunt. » 
important common feature between them in matters of philosophical practices and philosophical education. This practice of philosophical debates which Pico regards as most honest struggles (honestissima certamina) is thus more than necessary for the wisdom which should be obtained (adipiscenda sapientia) ${ }^{18}$. All future philosophical culture will become sluggish and sleepy if those philosophical contests and battles are to be taken away from it ${ }^{19}$. Pico is advocating a vivid and meaningful philosophical discourse - one which really matters both to those who participate in it and to those who are only following it. The result of this philosophical practice is becoming more learned (doctior) and better instructed (instructior) for future debates ${ }^{20}$.

Pico's project provoked many critical reactions. The second part of this paper will be dedicated to one of these reactions by Giovanni Caroli, who also reacted against the growing popularity of Savonarola. Caroli belonged to a group of intellectuals which should be called "Renaissance scholastics". Let us consider this phrase first, and then present some biographical facts concerning Caroli and discuss his reaction.

The phrase "Renaissance scholastics" already rejects the historiographical dichotomy between the Middle Ages and the Renaissance and suggests, instead, a more complex relation between different philosophical discourses in a Renaissance setting. It takes into account, for instance, the complexities of different scholastic schools of thought in the fourteenth century on the one hand, and the new methods and practices of learning employed by the humanists on the other. In doing so two distorting images should be rejected : the image of one, monolithic, dark, traditional and not original scholastic philosophy on the one hand, and the image of a secular, pre-modern, enlightened and progressive humanist thinkers on the other ${ }^{21}$.

Giovanni Caroli (1428-1503) is one good example of a Renaissance scholastic. A relatively unknown figure - nowadays - in Florentine intellectual history of the last decades of the Quattrocento, Caroli was a man who had a share in the two great traditions of his time: the

18. Ibid., p. 76-78: « ... significasse nobis, quam honestissima hoc genus certamina adipiscendae sapientiae oppido quam necessaria. »

19. Ibid., p. $78:$ «... si hos congressus, haec bella substuleris, somniculosa et dormitans futura sit omnis philosophia. »

20. Ibid., p. 80: «Quo fit ut imbecillissimus quisque non detrectare modo, sed appetere ultro eas iure possit et debeat, quandoquidem qui succumbit beneficium a victore accipit, non iniuriam, quippe qui per eum et locupletior domum, idest doctior, et ad futuras pugnas redit instructior. »

21. On this see e.g., John Monfasani, « The Renaissance as the Concluding Phase of the Middle Ages », Bulletino dell'Istituto Storico Italiano Per Il Medio Evo 108 (2006), p. $165-185$. 
scholastic and the humanist. Despite his position as a leading Dominican theologian in Florence and his obvious preference for the scholastic tradition (and his explicit critique of the new humanist fashion), his writings reveal a far more complex picture, in which we find the unique fifteenth-century mixture of traditional ideas and new notions. In this respect he remained loyal both to his spiritual mentor, the influential Florentine archbishop Antonino Pierozzi, and to his teacher and colleague at the University of Florence, the humanist Cristoforo Landino. Caroli was three times prior of Santa Maria Novella, taught theology at the Studium generale there, which was part of what Paul F. Grendler called a " confederation of the studia monastica under the name of the civic university but with limited participation by the latter », which formed the Faculty of Theology of the Studio fiorentino, the University of Florence ${ }^{22}$. He was involved in the observant reform movement, and during the 1490s led the opposition to the influential preacher of San Marco Girolamo Savonarola. Caroli was a prolific author, who wrote biblical exegeses, a history of Florence, and polemical writings against Savonarola, Giovanni Nesi, and Pico. He was deeply involved in both the religious and intellectual life of his time. Despite his obvious importance to Florentine intellectual history of the last decades of the fifteenth century, and the fact that he was involved in almost every central debate concerning theological, philosophical, or political matters, almost none of Caroli's writings have been published or critically edited until the present day, and they are very rarely discussed in detail and on their own merits in modern scholarly literature ${ }^{23}$.

22. On the institutional status of theology in the Italian universities and in the academic life of the Renaissance, see Paul F. GrEndLER, The Universities of the Italian Renaissance, Baltimore, John Hopkins University Press, 2002, p. 353-392. The citation above is from p. 357.

23. On Caroli see Stefano Orlandi, O. P., Necrologio di Santa Maria Novella : 12351504. Testo e commento biografici, vol. 1, Florence, L. S. Olschki, 1955, p. 203-205 ; vol. 2, p. 353-380. For a description of the manuscripts of Caroli found in the library of Santa Maria Novella see G. POMARO, «Censimento dei manoscritti della biblioteca di S. Maria Novella - parte II : sec. XV-XVI », Memorie Domenicane 13 (1982), p. 203-255. The most profound historical analysis of Caroli and his role in the intellectual history of fifteenthcentury Florence can be found in the works of Salvatore I. CAMPOREALE; see especially « Giovanni Caroli e le "Vitae fratrum S. M Novellae" - umanesimo e crisi religiosa (14601480) », Memorie Domenicane 12 (1981), p. 141-267, including an appendix with Caroli's letter of dedication to Cristoforo Landino, his general introduction, and his seven introductions to each of the Vitae, on p. 236-267 ; and his Giovanni Caroli - dal "Liber dierum" alle "Vitae fratrum", including an appendix containing the third book of the Liber dierum lucensium, on p. 218-233. Camporeale's other works on Caroli are: « Giovanni Caroli, 1460-1480 : Death, Memory, and Transformation », in Marcel TeTEL, Ronald G. WitT, and Rona GofFen (eds.), Life and Death in Fifteenth-Century Florence, Durham, London, Duke University Press, 1989, p. 16-27 ; « Humanism and the Religious 
What was the problem, according to Caroli, with Pico and his ambitious project? In his late account against Pico's 900 Theses written in 1498 and entitled Super quibusdem conclusionibus Iohannis Pici Mirandule principis the Dominican presented his critique, from a theological point of view, of some of Pico's theses. Caroli's critique is important since it can clarify both Pico's intentions (beyond what we have in his Oration, Theses and Apology), and the way these intentions were received by contemporary philosophers and theologians. Caroli is putting his finger exactly on the heart of the matter : the relation and tension between theology and philosophy and between human and divine issues. He is pointing out that the status of theology as a special discipline is at stake : on the one hand it is a sacred or divine doctrine based on Scripture and on the articles of faith; on the other hand, as pointed out by Pico, it also has human aspects and the theological tradition includes many probable opinions and possible theories and speculations which should be discussed and determined as true or false. The development of the scholastic schools of the fourteenth and fifteenth centuries on the one hand and the new humanist methods and practices on the other brought the tension between faith, theology and human knowledge and disciplines (such as philosophy, history or philology) into a critical point which is reflected in Pico's project.

Pico, according to Caroli, by using too much philosophy and theoretical speculations in his theological accounts, is obliterating the superiority of dogma and of the contents of the articles of faith, which are more important as divine revelations than the debate and the interpretation which are only manifestations of the human intellect. In this regard, although Pico is according to Caroli, « a most erudite man » (eruditissimus vir), when he discusses theological questions, « he talks like a magpie » (Ergo in hac parte Picus ut pica locutus est, non ut assertor fidei catholice ut esse debuerat ${ }^{24}$.

Crisis of the Late Quattrocento - Giovanni Caroli, O.P., and the Liber dierum lucensium », in Timothy VERdON and John HENDERSON (eds.), Christianity and the Renaissance. Images and Religious Imagination in the Quattrocento, New-York, Syracuse University Press, 1990, p. 445-466 ; « Mito di Enea e crisi mendicante - il Liber dierum (1460-1462) di Giovanni Caroli O.P. », Memorie Domenicane 30 (1999), p. 5-18. See also Amos Edelheit, Ficino, Pico and Savonarola. The Evolution of Humanist Theology 1461/2-1498, Leiden, Brill, 2008, p. 49-122.

24. Giovanni CARoli, Super quibusdem conclusionibus Iohannis Pici Mirandule principis, ms. Florence, Biblioteca Nazionale Centrale, Conv. Suppr. C.8.277, ff. 224r$263 \mathrm{v} ;$ f. $224 \mathrm{r}:$ «... super quibus [conclusionibus] meam sententiam scriberem, vero quod acerbiores mihi iniuste sint, ut non satis eo ab eruditissimo viro considerate »; f. 248v : «Ergo in hac parte Picus ut pica locutus est, non ut assertor fidei catholice ut esse debuerat. » For a detailed analysis of Caroli's account see Armando F. VERDE, Lo studio fiorentino 1473-1503: Ricerche e documenti. vol. IV : La vita universitaria, 3 vols., 
The essential difference between Caroli and Pico lies in their different motivations : while Pico is indeed focused on the theological tradition as such, and on a critical account of this tradition in the form of a debate where the concepts "faith" and "theology" are being examined, Caroli is more concerned with the theological implications of Pico's intellectual efforts in which the young philosopher wants to use in every divine matter philosophy or dialectic, and in doing so he is necessarily wrong in many of these matters ${ }^{25}$. What, then, will be the alternative, according to Caroli, of doing theology?

In order to deal with this question let us examine, in the last section of this paper, how exactly the different motivations of Caroli and Pico are manifested in their different interpretations of the first of the Penitential Psalms.

Caroli's Espozitione dei Salmi penitenziali - just like most of his texts - has been hardly ever discussed by modern scholars; it is mentioned, with a brief description, in Stefano Orlandi's list of Caroli's manuscripts found in his Necrologio di Santa Maria Novella : 1235-1504, which was published in 1955. The text is found in a single autograph manuscript, and it is written in Italian, a fact which makes it more probable that this exposition is the result of Caroli's sermons on these Psalms delivered during his long career as a preacher in the Florentine churches.

In the proem, after pointing out the divine inspiration of Scripture, Caroli follows Jerome and Augustine in emphasizing the importance and singularity of the Psalms in comparison to other parts of the Bible. The excellence of the Psalms is accepted by both the Latin and Greek churches, claims our theologian ${ }^{26}$. But among the different chapters in the Book of Psalms, some are more glorified thanks to a certain quality they contain. Among this special group of Psalms we find also the Penitential Psalms. What is so special in these Psalms? They contain many more major mysteries than the rest of the Psalms. These Psalms are most useful and necessary for making one more familiar with the Christian mysteries such as the triune God (placitare is the term used by Caroli, which can be best explained by the Italian phrase intimare con decreto), and thus are essential for our salvation. The aim of this

Florence, L. S. Olschki, 1985, p. 1348-1361. The citation from f. $248 \mathrm{v}$ can be found on p. 1356.

25. Ibid., ff. 263r-v : « Mirandula autem noster, volens in omnibus philosophiam vel dialecticam deservire divinis rebus, in multis perperam ageret necesse fuit. 》 See also VERDE, La vita universitaria, op. cit., p. 1360-1361 (but Verde is wrongly referring to f. 263v).

26. G. Caroli, Espozitione dei Salmi penitenziali, ms. Florence, Biblioteca Nazionale Centrale, Magl. XL.46, f. 1r : « Niente di meno probata da ecclesia la excellentia de salmi nella chiesa di Iddio el latina e grecha, secondo san Hieronimo e santo Agustino... » 
exposition is to propel the souls of believers towards devotion and to emphasize the prophetic and mystical meaning in these Psalms ${ }^{27}$. But beside this known topos, Caroli is also pointing out that the Penitential Psalms are most useful and necessary for both secular and religious people in coping with their daily troubles caused by their own sins. They contain a kind of virtue implanted in them by God, through which it might be possible to help those sinners. Citing 2 Co 3, 6 (littera occidit spiritus autem vivificat), Caroli emphasizes the importance of spiritual knowledge in what seems like a methodological remark on interpretation ${ }^{28}$. Caroli's exposition is arranged logically, focusing on the practical issue of helping sinners in finding their way to penitence. For this reason, he does not begin with an exposition of the Penitential Psalms themselves, but rather precedes it with his interpretation of Psalm 113 (in exitu Israhel de Aegypto), to prepare the ground for discussing the Penitential Psalms, since, as he explains, the sinner who will use the Penitential Psalms should first know how to get out of Egypt, which symbolizes servitude to sin. He must understand how he got there and why, and what might be the remedy for his situation. After explaining the Penitential Psalms, Caroli ends his exposition with a discussion of Psalm 90 (qui habitat in adiutorio altissimi), in order to show the way to divine goodness. Caroli's exposition is in fact an account of the psychological process of penitence. Asking people to make penitence was a regular formula used in sermons. But how should one start ? In this exposition Caroli is acting as a moral theologian, using his experience as a preacher and a confessor, and showing the way from the lowest possible position to the highest one. For him, the starting-point is

27. Ibid., ff. $1 \mathrm{r}-1 \mathrm{v}:$ : La qual cosa io considerando anchora il desiderio tuo [Caroli is referring here to his friend Bernardo Gondi, to whom he dedicated this exposition], e dessendo in questi peccati nostri noi [1v] assai nell'animo quanto mi pensai essere buono in qualche per sodisfare al tuo desiderio e al mio. E sine di alchuni certi expositioni per suscitar gli animi nela devotione di quegli e far più noto lo intelletto propheticho misticho e [...] non avessi gratia provata nelle consuetudine delle sancte scripture. »

28. Ibid., f. $1 \mathrm{v}:$ «Per se addunque i salmi penitentiali per più utili a noi e necessarii veduti in quante tribolationi ci troviamo tutti, e seculari e religiosi e in quanto disordine nel quale siamo, per divina permissione, non per altro che per nostri peccati. E perché si nel la intelligentia di questi salmi veniamo a pregiare e rendere di quegli in colpa. Forse che per la bontà di iddio e per la virtù di questi salmi plantando di Iddio ne potremo aiutare altri. E misterii che in questi si contragono sono gravissimi e molto degni e allo ingegno humano e divoto molto accomodanti, ma bisogna con intelletto e sapere spirituale gustandogli, viene da nostri sempre del detto apostolicho che dice: Littera occidit spiritus autem vivificat $(2 \operatorname{Co} 3,6)$, perché altrimenti non fano crescere il desiderato fructo. Non è segreto in questa expositione la dichiaratione di persona ma solo lo instincto, ma dato lo trino iddio nel pensiere mio, non che per questo io attribuisca la doctrina a me, ma quelche è stato detto, poi passato da nostri doctori in diversi luoghi, e adversi propositi, legho qui ratio certo insieme e rechato al proposito mio. » 
most significant, and without it no real penitence is possible, and this stage includes awareness of one's own situation as a sinner, together with a deep understanding of the reasons for one's sins.

Let us discuss now Caroli's exposition to the first Penitential Psalm, that is Psalm 6 (Domine ne in furore tuo). The structure of the exposition is quite simple : our commentator first cites each verse, and each citation is followed by an explanation which is thematic and allegorical. From time to time Caroli cites verses from other parts of the Bible as part of his explanation, whenever he thinks that this can help him with his argument. Only once does he cite a non-biblical authority: Augustine (f. 37v). Caroli skips the detailed literal explanation in most cases by simply translating the verses into Italian.

Caroli's first concern, stemming out of verse 2 where anger (furor) and ire (ira) are mentioned, is to determine the exact relation between God and these passions. The aim of both passions are vengeance (vendetta) and justice (giustitia), but only the last, which is a positive passion, can be ascribed to God, Who in any case is not subject to such passions. The prophet's intention by mentioning these passions is to warn sinners not to reach their death and the final judgment without penitence and indulgence ; for this reason he is begging God not to delay His judgment and punishment but rather to punish him during this present life, when mercy and correction are still possible and meaningful. Otherwise the sinner remains evil until the final judgment, when it is too late. The present life, while there are still hope and mercy, is thus the arena of the act of penitence. Reconstructing the psychological mechanism of penitence via an exposition of the first Penitential Psalm is thus the subtext here.

The first step in this mechanism of penitence is a self-recognition by the individual of his weakness, shown in verses 3-4: « Have mercy on me O Lord, for I am weak : heal me, O Lord, for my bones are troubled. And my soul is troubled exceedingly... » (I am using the Douay version). Caroli emphasizes that although the prophet admits that he is seriously weak or ill, he is not yet dead; he thus begs God for a hope of salvation :

But the prophet says : O Lord, I am well aware that I am seriously ill, but I am not yet dead. And give me now hope of salvation, I confess and recognize that I am seriously ill, but I am not dead. ${ }^{29}$

Caroli presents an analogy between the bones as the rulers of the body and the virtues as the rulers of the soul. Thus, the bones are

29. Ibid., ff. 34v-35r : «Però dice el propheta : o signore, io sono bene gravemente infirmo, ma io non sono anchora morto. E da mi anchora speranza di salute, confesso e conosco che sono gravemente infirmo, ma io non sono morto. » 
analogous to the virtues, and the physical state of disturbance is transformed into a moral disturbance ${ }^{30}$. This moral disturbance reaches its high point in Caroli's interpretation of verse $7:$ : I have laboured in my groanings, every night I will wash my bed I will water my couch with my tears. » This is the lowest and most difficult state of the sinner, when he truly confesses his sins and struggles against his own habits as a sinner. At this point the Holy Spirit interferes, causing the first movement in the sinner's soul towards penitence, since, Caroli claims, it is impossible to do it without the grace of God. Here our commentator follows an image found in Thomas Aquinas :

And he [the prophet] calls conscience his own bed since just like in bed we repose in it... ${ }^{31}$

Caroli puts the notion of conscience at the heart of the mechanism of penitence. While the conscience of the sinner is constantly disturbed and is never at rest, the one who is truly doing penitence is trying hard to clean his conscience and keep it away from any stain of sin. The connection between virtues and conscience is explained, for instance, at the beginning of Antoninus' Summa theologiae, where the Florentine archbishop, who was Caroli's mentor, mentions $f b 1,19$, where four corners of a house are described as being struck down by a desert wind ; this event is interpreted by Gregory the Great in terms of our soul being demolished by a multitude of impure spirits which turned upside down our conscience from its state of tranquility. The four corners represent the edifice of our soul : prudence, temperance, courage, and justice ${ }^{32}$. Conscience here, according to Antoninus, who follows Gregory closely, is a kind of internal equilibrium upon which the four cardinal virtues, representing the edifice of our soul, lean. When conscience is disturbed, the whole edifice is shaken. Caroli's image of conscience as bed is

30. Ibid., f. $35 \mathrm{r}$ : « Ove è da notare che come l'ossa naturalmente regnano il corpo, così naturalmente le virtù regnano l'anima. » The analogy between bones and virtues is a known topos in biblical interpretations; see e.g., Augustine, Enarrationes in Psalmos 31, 2, 13 ; GREGORY THE GREAT, Moralia in Iob 23, 24, 48.

31. Ibid., f. $37 \mathrm{r}$ : «E chiama la constientia il letto suo perché come nel'letto noi ci riposiamo...» See Thomas Aquinas, In Psalmos Davidis expositio, in Opera omnia, vol. 18, Paris, Louis Vivès, 1876, p. 255 : « Dicit autem, Lacrymis stratum meum riqabo, quia etiam in lecto jacens plorando perfundebat pannos lecti, quasi irriguum lacrymarum. Moraliter, lectus in quo homo quiescit, est conscientia, hanc lavat homo per lacrymas in poenitentia... »

32. Antoninus of Florence, Summa theologica, vol. 4, Verona, Ballerini, 1740 ; repr. Graz, Akademische Druck \& Verlagsanstalt, 1959, p. 14 : « Figuratur etiam per quattuor angulos domus Job i, que est conscientia secundum Gregorium in moralibus [Moralia in Iob 2, 49]. » The whole discussion is of the four cardinal virtues which have been mentioned earlier. 
influenced by this intellectual milieu. This image is concrete and simple, unlike other images used for conscience such as the heart or some abstract interiority. And thus :

And God, being most just, cannot allow the ugliness of blame to exist without the beauty of justice. And this is the cleaning of conscience. ${ }^{33}$

Caroli ends his exposition of Psalm 6 by emphasizing the role of shame and the importance of free choice (libertà dello arbitrio) in the mechanism of penitence, following verse 11 : « Let all my enemies be ashamed, and be very much troubled : let them be turned back, and be ashamed very speedily. »

Caroli's emphasis and focus is on the present life of the individual and his state in via, under human constrains, weaknesses, and possibilities. By having the freedom of choice the act of penitence becomes meaningful. The first Penitential Psalm is a prayer not to reach death and final judgment without penitence; God must judge us now, but this depends upon man through the voluntary act of true penitence.

A comparison between Caroli's exposition and Pico's reveals some interesting differences both in style and content. Pico's exposition of Psalm 6 which is written in Latin is very formal and not personal in style; the humanist uses an academic style with formal divisions and a formal structure ${ }^{34}$. Pico presents a lot of authorities, both Jewish and Christian, he gives a detailed literal exposition, sometimes word for word, comparing different authorities, translations, and interpretations. His exposition reads almost like a compilation of all the interpretations of this Psalm. A good example can be found in the literal exposition of verses 3-4, where Pico discusses the phrase turbata sunt ossa mea while mentioning Ibn Ezra, Jerome, and Augustine ${ }^{35}$. For Caroli it was enough to simply mention that bones represent virtues in order to move from the physical to the moral level. In his literal exposition of verse 2 Pico does not mention the need to be corrected during the present life, but is focused on the way of correction : non ut damnandus sed ut purgandus. This is nice Latin, but many readers may miss the essential theological point here which was emphasized by Caroli : one should not wait until death and the final judgment to be corrected, correction must take place

33. G. CAROLI, Esposizione dei Salmi penitenziali, f. 38r : «E non pote Iddio - essendo giustissimo - che sia la bruttura della colpa sanza la bellezza della giustitia. E questo è il rimorso della constientia. »

34. Pico's exposition of Psalm 6 can be found in G. Pico Della Mirandola, Expositiones in Psalmos, ed. Antonino Raspanti, Florence, L. S. Olschki, 1997, p. 62-78.

35. Ibid., p. 66 : « Scribit Avenazra ex his lectionibus magnitudinem doloris ostendi ut etiam ossa sensus expertia illum sentiant. Hieronimus, Augustinus et alii plerique per ossa virtutes animae intelligunt. » 
now in the present life and under God's mercy. Conscience is not mentioned at all by Pico, and his moral exposition of verse 7 is focused on sensual sins represented by the image of the bed ${ }^{36}$. It is interesting, on the other hand, to find in Pico's exposition « the cunning tricks of an ambushing demon» (insidiantis daemonis astus) and «impious demons » (impii daemones) threatening the individual, while the notion of shame does not seem to play a role in the moral correction of the individual.

Obviously Pico and Caroli are representing two different points of view : while Pico is writing for the learned, humanists or theologians, who would appreciate, for instance, the many sources he uses, Caroli is writing for the believers in a personal and non-authoritative style, and he hardly mentions authorities. For Pico it is an intellectual task, for Caroli it is more a pastoral task. For this reason penitence is not emphasized in Pico's exposition ${ }^{37}$, since it is not in the text, while the psychological mechanism of the voluntary act of penitence is the subtext of Caroli's exposition. In this respect Pico's exposition is close to a modern commentary on a biblical text. But if it is true that one important aspect of modern moral thinking is the emergence of the individual conscience as a source of the agent's moral judgments and actions, then Giovanni Caroli, while playing his part in the complicated discussions of moral psychology among Renaissance and Early Modern thinkers, should be regarded as one of the forerunners of such modernity no less then Giovanni Pico della Mirandola.

36. Ibid., p. 76 : « Iusto dolore confectus contritusque singulis noctibus, quibus defluere delitiis et vitiis solebam et iram atque furorem iustissimae tuae vindictae provocare, conabor contribulato spirito (gratissimum tibi sacrificium) colligationes impietatis dissolvere et contractas in animo peccatorum maculas ob sensus corporis, in quo veluti in lecto voluptatum delitiamur et putridae libidinis strato marcescimus, lacrymis moeroris et afflictionis eluere. »

37. The term is mentioned three times in the moral exposition; see Pico, Expositiones in Psalmos, p. 74 : « Hosti pepercisti, Domine, et inter terrestris tuae militiae munera nos iterum collocasti, poenitentiae sacramento in pristinam libertatem dignitatemque restitutos »; p. 76: «Poenitentiae igitur condona spacium, differ terminum primae mortis, ut de secunda morte, protectus scuto tuae misericordiae, triumphem »; « Non moriar igitur, sed vivam; diuturno etenim poenitentiae tempore opus est mihi, si expiare lacrymis omnia delicta velim. » 
ABSTRACT. - Philosophy and Theology in an Oral Culture : Renaissance Humanists and Renaissance Scholastics. By Amos EDELHEIT.

In the following paper, we focus on the dialectical tensions between Renaissance humanists and Renaissance scholastics as they are reflected in the oral culture of sermons, university lectures and public debates in Florence of the late Quattrocento. Our aim is to show how this oral culture reflects important aspects of the new atmosphere which we call "The Renaissance", which does not always correspond to some popular and antiquated historiographical images of a secular and anti-religious movement. Sermons delivered in the religious confraternities by humanists like Francesco Berlinghieri, Giovanni Cocchi, Christoforo Landino and others stand at the centre of the first part of the paper; we then consider one of the most famous documents of the Renaissance: Giovanni Pico della Mirandola's Oration on the Dignity of Man. The second part of the paper focuses on Giovanni Caroli's reaction to Pico's project and offers a comparison between Pico and Caroli, while discussing their different motivations and methods with regard to philosophical and theological matters.

KeYwords: Giovanni Caroli - Giovanni Pico della Mirandola - sermons Renaissance scholastics - Renaissance humanists.

RÉSUMÉ. - Philosophie et théologie dans une culture orale : humanistes renaissants et scolastiques renaissants. Par Amos EDELHEIT.

Dans cet article nous examinons les tensions dialectiques entre les humanistes renaissants et les scolastiques renaissants telles qu'elles sont représentées dans la culture orale des sermons, des conférences universitaires et des débats publics à Florence à la fin $d u$ Quattrocento. Nous tâchons de montrer comment cette culture orale reflète d'importants aspects de ce nouvel environnement que nous intitulons «la Renaissance» et qui ne correspond pas toujours à certaines notions historiographiques populaires surannées d'un mouvement laïc et antireligieux. Les sermons prononcés au sein des fraternités religieuses par des humanistes tels que Francesco Berlinghieri, Giovanni Cocchi, Christoforo Landino, entre autres, constituent le principal objet d'étude de notre première partie; nous examinons ensuite l'un des documents les plus importants de la Renaissance: De la dignité de l'homme de Pic de la Mirandole. Dans notre deuxième partie nous nous penchons sur la réaction de Giovanni Caroli au projet de Pic et dressons une comparaison entre les deux en abordant les intentions et méthodes qui distinguent leurs approches respectives de la philosophie et de la théologie.

Mots-CLEFs : Giovanni Caroli - Jean Pic de la Mirandole - humanistes de la Renaissance - scolastiques de la Renaissance - sermons. 